\title{
Strategic Management Analysis of Universal Music Group Under Covid-19
}

\author{
Simiao Deng ${ }^{1, *}{ }^{*}{ }^{\prime}$ Yuting $\mathrm{Lyu}^{2, \dagger}$ Fanqi $\mathrm{Xu}^{3, \dagger}$
}

\author{
${ }^{1}$ Beijing No.8 High School, Beijing, 100033, China \\ 2 The Barstow School Ningbo Campus, Ningbo, 315202, China \\ ${ }^{3}$ Ulink College of Shanghai, Shanghai, 201615, China \\ *Corresponding author.Email: guanghua.ren@gecacdemy.cn \\ ${ }^{\dagger}$ These authors contributed equally.
}

\begin{abstract}
This essay is mainly focused on the 4ps model of Universal Music Group (UMG). It divides into Literature review, 4p discussion, financial analysis. The first part is about integrated marketing communication, which is a business strategy. Then it goes to the $4 \mathrm{p}$ part: product, price, promotion, place. It gives out the background information, current situation, and business strategies of UMG. It shows that UMG has a number of high-quality products, and UMG gives out different levels of products to different kinds of target consumers. It highlights changes UMG has made with The Times, such as moving from offline to online. The most significant one is the example of Tiktok cooperation in the place analysis. It indicates the importance of streaming media operation in later years. UMG reinforces the internet and tries to be more up-to-date. The third part is financial condition. It introduces 3 bullet points. The first one is the revenues of UMG are mainly from streaming media. The other two are about the stock exchange and the industrial competitiveness of UMG. It gives out many real figures and databases to prove this idea.
\end{abstract}

Keywords: Covid-19, the Universal Music Group, 4Ps Modal, Strategic Management.

\section{INTRODUCTION}

In recent years, with the development of the economy, the increase of residents' income, and the improvement of living standards, people have gradually changed from material needs to spiritual needs. More and more people are consuming in the music market, and the scale of the music market has grown steadily. Driven by the Internet and other technological fields, streaming media has continued to develop. The impact of the novel coronavirus has hindered the offline development of the music industry. Online music platforms, record companies, musicians, etc., have expanded online businesses to keep up with the development of the times and cater to the public Entertainment needs.

The company studied in this paper is Universal Music Group. Universal Music Group is one of the world's largest record companies. It evolved from Polygram. In 1998, a company called Seagram merged with many music companies and built a huge empire. Universal Music Group has 48 subsidiaries in 46 countries, recording, publishing, and selling music worldwide. While COVID-19 hit many businesses in 2020, UMG' s overall sales were strong. In total, UMG generated $\$ 11.4$ billion in music-streaming revenue in the year to September 2020, up 22.6\% from last year.

\subsection{Literature Review}

For the theory of strategic management, domestic and foreign scholars have conducted long-term research. This section summarizes the literature from this theory's concept, development, and schools and specifies the diversification strategy. Strategic management is an effective strategy to achieve the final goal by determining the far-reaching development goal of the enterprise. Strategic management can be defined as the formulation of enterprise strategy in the narrow sense and the positioning of strategic enterprise management in the broad sense [1]. But so far, different scholars still maintain different views on the definition of strategic enterprise management.

These are the different views of several foreign scholars. Igor Ansoff believes that strategic management is a kind of decision rule, which is mainly related to the organizational activities of enterprises; Kenneth Andrews 
believes that strategic management is a mode of decisionmaking, which can clarify the goals of the enterprise, show the scope and type of business, and specify the policy of enterprise activities; Michael Porter believes that strategic management is a choice to avoid excessive competition with rivals in the market by improving the firm's own advantages. Later, the famous scholar Mintzberg proposed five words beginning with the letter P to define strategy, and they are "play", "pattern", "position", "perspective", and "play" [2]. In the 1960s, Alfred A. Chandler, A famous American scholar, defined strategy as the decision of enterprises' long-term goals in his book Strategy and Structure, which marked the beginning of enterprise strategy research.

At present, the research on management strategy can be roughly divided into three stages. The initial stage is the analysis of strategic management based on the market environment, emphasizing the application of external and internal structure of enterprises and a series of strategic management processes. The next stage is to analyze the enterprise structure and competitive advantage based on the direction of economic strategy formulation. The last stage is a new development trend in this field, and the concept of core competitiveness is put forward for the first time [3]

The research school of strategic management can be divided into ten schools: design school, planning school, positioning school, creativity school, cognitive school, learning school, power school, cultural school, environmental school, and structural school. Different schools have their own characteristics, among which the design school represented by Kenneth Andrews and the planning school represented by Igor Ansoff are the most representative. The design school believes that the senior management of the enterprise should be responsible for the strategy formulation, which is a conceptual method. This school mainly contributes to the SWOT analysis model. The planning school believes that strategy formulation is formal. It is controlled and continuously standardized. The school puts forward that strategic management is mainly divided into overall and competitive strategies [4].

The process of strategic management is divided into three steps: first, the formulation of enterprise strategy, then the implementation of strategy, and finally, the evaluation and control of strategy. First of all, the strategy formulation needs to be clear enterprise goals and then strategic analysis. In the process of strategic analysis, the company must analyze from the external and internal perspective to ensure that the company can make rational use of resources and identify opportunities and threats, strengths and weaknesses. The second step is the implementation of the strategy, develop a strategy to advance to the goal. The plan should be detailed and flexible and constantly optimize the internal staff structure. Finally, the evaluation and control of strategy in this process, enterprises need to always pay attention to the situation of strategy, continuous evaluation, and adjustment [5].

Effective implementation of strategic management requires the following points. First, companies must be analyzed from a global perspective. Second, the strategy implementation should be flexible, the internal staff structure should be continuously optimized, and the allocation of resources should be adjusted according to the market situation. Third, make the strategic body diversify, the value of ordinary employees more and more important, rather than only the top management control the fate of the enterprise [6].

There are three categories in strategic management: cost strategy, centralization strategy, and diversification strategy. Among them, scholars have conducted in-depth research on diversification management. Diversification strategy theory is a kind of strategic management, which means that enterprises carry out a number of businesses in many industries at the same time.

There are three perspectives on the relationship between diversification theory and corporate performance: diversification discount, diversification premium, and diversification neutrality theory. Diversification discount refers to the decline of corporate value after the implementation of the diversification strategy. Diversification premium, on the other hand, contributes to the increase of corporate profits. There is also a diversification neutrality theory, and diversification strategy has no significant impact on the value of enterprises [7].

The motivation for implementing diversification strategy is mainly as follows: first, to make full use of surplus resources. A diversification strategy can improve the efficiency of resource utilization of enterprises, explore the utilization potential, capital strength, human resource reserves, sales channels, and other resources that enterprises can explore. Second, for the sake of synergistic effect, it means that the cost of centralized operation of multiple businesses avoids the low cost of a single business operation [8]. Third, to effectively reduce the uncertainty of corporate cash flow. Fourth, dispersing business risks can be transferred by diversification [9].

\subsection{Gap}

In conclusion, most of the previous research on strategic management is based on the global perspective and lacks research on the abnormal economic form of COVID-19 from the perspective of enterprises.

And in the past, qualitative research was preferred. This paper adopts qualitative and quantitative research methods.

Based on this, this paper takes the COVID-19 epidemic as the research background and Universal 
Music Group as the research object to study the company's strategic management and future development.

\section{DATA AND METHOD}

\subsection{Data}

The data used in this paper are from Cruchbase, and the Universal Music Group company is taken as the study sample. The study period of the sample is from 2016 to 2018. There are mainly two types of data involved in the study. One is the current financing situation of the company, including financing times, financing amount, financing methods, etc. The other is the company's financial data, including the company's output, net profit, total revenue, growth rate, etc.

\subsection{Method}

This paper uses the 4Ps model to study and analyze the strategic management and future development of UMG company. The 4Ps theory is a marketing mix strategy proposed by American scholar Jerome McCarty in the 1960s [10]. The 4Ps are product, price, place, and promotion. To gain more profits, enterprises need to pay attention to product development and put the function and uniqueness of products first. Then, according to the market positioning, enterprises need to formulate different pricing strategies, select the most suitable sales channels, and adopt a series of marketing methods, including advertising, public relations, and so forth, to sell products.

\section{RESULTS AND DISCUSSION}

\subsection{Ps Model}

\subsubsection{Product}

The product mainly includes its functionality, brand, packaging, services. Product is the basis of a company. In $\mathrm{UMG}$, the dominating products are singers and their songs. They are the most important part of the music company because it decides UMG's products' quality and future profits. Universal music groups gather many famous singers over the long history: like the Queen, Taylor Swift, Justin Bieber, Lady Gaga. These worldfamous artists provide high revenue and create a very well-known brand for Universal Music group. The company has a very good eye for selection. Because just like these singers, they all have a high degree of discussion and attention in their respective countries.

Furthermore, to make their products more famous and make the relationship between singers and their fans closer, UMG's singers have their own derivative products. Many famous stars have their own website to sell their related products: such as T-shirts, Physical albums, posters. It might not be expensive, but it connects closely to these famous stars' characteristics which encourage fans to spend. They use a smart business strategy to do the multiplex development and even realize a popular trend. Take Billie Eilish as an example. Her singing style is unique, and she has reinforced this image in fashion. She likes the suit that ordinary people cannot accept big logo is full of the whole body, but the hair color that this kind of clothes has individual character extremely as a result of her collocation and act the role of with her oneself echo is very good did not jump off feeling at all. Thanks to this, she has been promoted by many wellknown brands. The presentation in these advertisements has made the public know her better and broadened her popularity more greatly. Because of her high popularity, more people will come to know her work, and then many brands will continue to invite her to promote, thus forming a virtuous circle. Finally, the company can earn more profits with it.

For the service part, it is mainly targeted to Online customer service consultation. UMG needs workers to solve the consumers' questions. For the package, consumers have various choices, but most of the time, the price will increase when the packaging is better. People can buy the suitable one in their own financial situation.

\subsubsection{Price}

Price in $4 p$ strategy is mainly about basic price, discount, time of payment. A price is just a number, but it is very important: it influences the consumer's buying willingness, buy how many. These factors will resolve the competitiveness of UMG in the industry and how much revenue they can get. So UMG managers need to decide each price carefully, make sure it can bring the most benefits.

First, UMG needs to consider consumers' purchasing power. For music working, most people would not like to put a lot of money on it because it is unnecessary entertainment. If you are set your price too high, they will change to other companies' products. No company can make sure they have the complete mastery to let consumers buy it.

Also, the competition in the music trade is fierce UMG cannot make uncertain decisions even it is the leader in this industry. So for most UMG products' prices are cheap. A digital album is around 20 yuan per one. These are face to the whole music market. Because it is cheap, so some un-fans people will also buy it. This strategy is low the revenue per album but has a huge customer base, and then it adds up to a lot. However, for derivative products, like T-shirts, a physical album about hundreds of yuan is face to the whole fans. It is affordable to fans, so the revenue is ensured. These products connect the star and fans, making their relationship closer.

Finally, the most expensive one is the tour ticket. Only parts of fans can buy it. They divide the concert into 
different zones and set different prices. For UMG, it has many famous singers whose tickets can sell out in few seconds. Consequently, they can raise the price to a high level, and they don't need to worry about sales because the fans think it is rare to meet their idols once, so they are glad to buy it. But it should not reach a whopping price, or consumers will not buy it.

\subsubsection{Place}

Placing Strategy mainly refers to the realization of marketing objectives by enterprises using selecting distribution channels and organizing the circulation of commodity entities in a reasonable manner, including the combination and application of controllable factors related to distribution such as channel coverage, commodity circulation links, middlemen, the establishment of outlets, storage, and transportation. Enterprises do not face consumers directly but pay attention to the cultivation of dealers, and the establishment of a sales network, the contact between enterprises and consumers is through distributors. And it is divided into a direct channel and an indirect channel.

Nowadays, more and more entertainment companies are choosing to sell their product and marketing online because the internet can spread information more quickly and easily by account published information, hot search list ranking, group communication.

So more people are biased to shop and pay attention to current events online because buy things offline is so troublesome. Also, online selling can cover a wider range of customers, even in different countries. Therefore, it will increase the whole selling revenue, and some of the costs can be saved, such as employing assistants, rents. I think the most representative one is the digital album. They release on the music app, for example, Apple Music, QQ music(china). Consumers can buy it only by a few manipulations on phones which only costs few minutes. After that, they can listen to it on this music app. Concurrently, the price of an online album is very substantial. Some of them are even free because of this low price. So some non-fan crowd will also buy it if they are curious about it. But for some fans want to buy the physical album for love. It is much expensive than digital music, which means the profits would decrease. Second, consumers also need few days to wait for the album to arrive. During this time, the singer will lose the highest publicity flow.

However, to keep pace with the new era, UMG cooperates with Tiktok. Tiktok faces the young. These people are more concerned and active in the entertainment industry. They are becoming the mainstream consumer for music because they get information more quickly and are more interested in streaming. In this cooperation, Universal Music should grasp certain customer resources in the early stage to face huge competition in the future. Tiktok has a good development prospect and provides huge flow, and it has more opportunities to reach high publicity in a short time. One of the most representative is the song "Old Town Road" by American rapper Lil Nas X, which has had more than 100 million streams on Spotify and topped the Apple Music charts worldwide. Universal music groups can do the same thing. So in that way, this kind of place corporation can provide huge financial support and publicity to the UMG. In the midst of the pandemic, the universal music group has also changed the channels through which it exports its works and merchandise to the public. Before the outbreak, many of the company's artists would hold multiple concert Tours to expand their popularity and hold offline events such as fan meets or new song launches and concerts. However, as the epidemic became more and more serious, the company changed many offline activities to online, using the Internet's strong communication ability to achieve higher achievements.

\subsubsection{Promotion}

Universal Music has always adopted an Integrated Marketing Communication. Integrated marketing is a long-term process of audience group as the center, accurate value evaluation, and sales promotion through various communication channels and means [11].

For example, "Gangnam Style", which exploded in 2012, used this method. The first is network marketing communication. This song uses YouTube to form the scurve communication of Rogers' diffusion of innovative theory on the Internet. The second is entertainment communication. "Gangnam Style" had a lot of imitation videos at the time, and the record company seized this opportunity. The third is event marketing. At that time, any event related to the singer Park Jae-sang could be publicized. The fourth is viral marketing, simple melody, magical dance, impactful images, and celebrity propaganda, making this song spread worldwide like a virus.

In addition, this song also makes the tourism industry hot, and some travel agencies will promote the locations that appear in the MV. To online marketing, traditional media such as newspapers, magazines, and television have also begun to follow up strongly.

\subsection{Financial Analysis}

In this part, we analyze the financial condition of this firm.

This firm has been invested in three rounds. Firstly, Tencent led a consortium to complete the purchase of a $10 \%$ stake in Universal Music Group.

On March 31, 2020, in the second round, Tencent Holdings announced that a consortium led by Tencent 
had completed the transaction of acquiring $10 \%$ of Universal Music Group (UMG) from Vivendi SE. The enterprise value of a 100 percent stake in Universal Music Group is $€ 30 \mathrm{bn}$, and the transaction value of a 10 percent stake in Universal Music Group is about $€ 3 \mathrm{bn}$. In the third financing rounds, Universal Music Group is funded by 3 investors. Bill Ackman and Tencent are the most recent investors, and they have raised a total of $\$ 7.8 \mathrm{~B}$ in funding over 3 rounds. Their latest funding was raised on Jun 21, 2021, from a Secondary Market round. Universal Music Group has made 2 diversity investments. Their most recent diversity investment was on Mar 27, 2015, when Houseparty raised \$14M. Also, Universal Music Group has acquired 7 organizations. Their most recent acquisition was Big Machine Label Group on Dec 13, 2019. They acquired Big Machine Label Group for \$300M. See Table 1.

Table 1. three rounds invested

\begin{tabular}{ccccc}
\hline Date & Round & NO. & Money & Lead \\
\hline $1 / 2020$ & $1^{\text {st }}$ & 1 & - & Tencent \\
$12 / 2020$ & $2^{\text {nd }}$ & 2 & $€ 3 \mathrm{~B}$ & Tencent \\
62021 & $3^{\text {rd }}$ & 1 & $€ 3.5 \mathrm{~B}$ & $\begin{array}{c}\text { Bill } \\
\text { Ackman }\end{array}$
\end{tabular}

\section{Data source:}

https://www.crunchbase.com/organization/universal-musicgroup

With Taylor Swift's re-recorded album Fearless (Taylor's Version) back at the top of charts worldwide and breaking countless records, the first-quarter results of Universal Music Group (UMG) have been announced. According to parent Vivendi, Universal Music Group's total revenue, which includes recorded music, licensing, and other businesses, rose $9.4 \%$ in the first quarter from a year earlier to 1.81 billion euros ( $\$ 2.20$ billion), or $\$ 24.5$ million a day or more than $\$ 1$ million an hour. Streaming media accounted for $55.7 \%$ of the revenue. By business segment, universal music Group recorded revenues of 1.48 billion euros ( $\$ 1.80$ billion) in the first quarter, up $10.8 \%$ from a year earlier. Streaming, the largest source of revenue, brought in 1.01 billion euros ( $\$ 1.23$ billion) for Universal's recorded music business in the three months, or 68 percent of the division's total revenue, up 19.6 percent from a year earlier. That figure means Universal is making about $\$ 13.6$ million a day, or about $\$ 568,000$ an hour, from streaming platforms worldwide. With live music events such as festivals and Tours still not fully recovered, the impact on Universal music's licensing and merchandising revenues continues. Revenue at Universal Music Rights was eur271m in the first quarter, up $6.9 \%$ from a year earlier, excluding the impact of foreign exchange. Still, merchandise sales and other revenues were down $10 \%$ from a year earlier.
In March 2021, Universal Music Group said it would raise $\$ 3.5$ billion by the end of April and had restructured its corporate structure to prepare it for an IPO this year. Vivendi currently owns 80 percent of Universal Music Group(UMG), with a Tencent-led consortium holding 20 percent. Under the plan, 60 percent of Universal Music Group will be spun off and listed on the Amsterdam stock exchange in the Netherlands by the end of 2021.

According to MBW, the world's top three record labels -- Universal Music, SONY Music, and Warner Music -- generated more than $\$ 13.14$ billion in recordsrelated revenue in 2018 , up to $\$ 1.04$ billion from the previous year. Universal Music's data performance is very eye-catching among them, with 5.731 billion dollars in the industry ranked first. Data showed universal's streaming revenue rose 39 percent in 2018, topping \$3 billion for the first time, an increase of $\$ 864$ million from the previous year, or an additional $\$ 2.4$ million per day. To sum up, Universal Music Group's economic aspects of the income indicators are far better than other competitors., See Figure 1 and Figure 2.

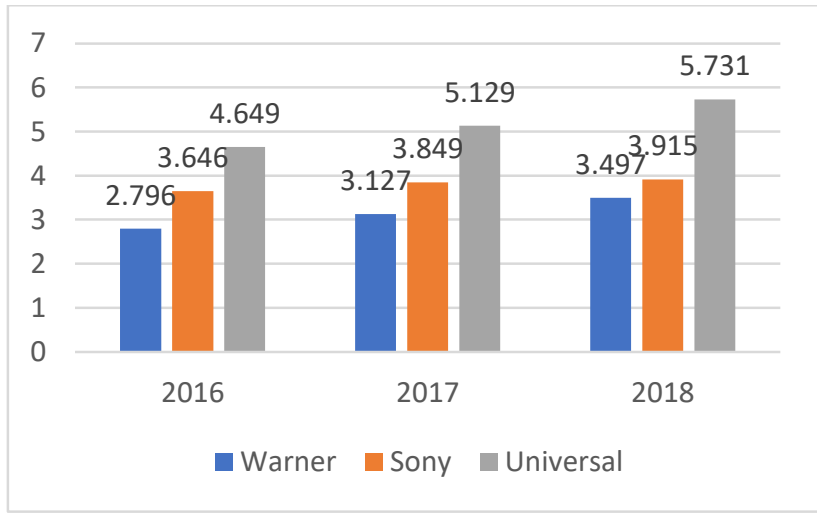

Figure 1. Major record company calendar year revenues $(\$ \mathrm{~m})$

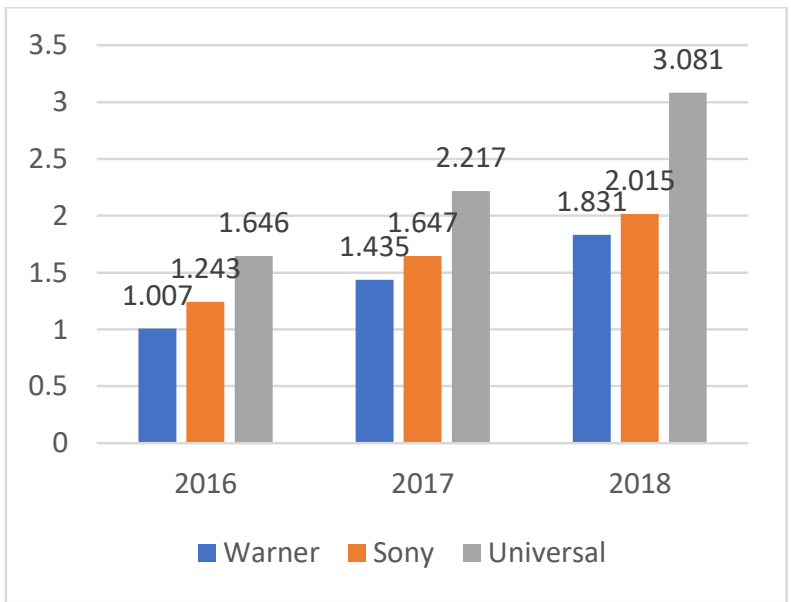

Figure 2. Major record company calendar year streaming revenues $(\$ \mathrm{~m})$ 


\section{CONCLUSION}

This paper uses the 4Ps model to analyze the strategic management and future development of Universal Music Group. In the $4 p$ strategy, which are product, price, place, promotion. It gives out real-life examples and data to provide the situation of UMG. These 4 parts show the main strategies and plans of UMG. Also, when the Covid-19 comes, UMG did some changes to solve these problems and ensure it can have enough profits. With the analysis of three rounds of financing and other financial situations, UMG's listed shares will be worth more than 33 billion euros, even more than its parent company. Therefore, its development prospects are worth looking forward to, and it can be seen that it is a worthy enterprise to be invested.

\section{Suggestions:}

First, UMG should think about how to maintain their high-quality music work. Nowadays, there is another famous and strong music company, such as Sony Music, Columbia Records. UMG should make their product irreplaceable, which means they need to find new singers who get your talents. They should have a unique personal music style. Although fewer people will love this kind of style, it will open a reputation for the new singers and improve the popularity of attention. The famous old singers can cooperate with these new singers who give the mutually benefits. UMG should also keep old singers active, so make sure they will not be forgotten in this fastpaced lifestyle and achieve long-term profits.

Second, UMG can set or adjust the price in two ways. The first is competition-oriented pricing, where UMG can study competitors' status, service, price, and supply. This ensures their strong competitiveness. Of course, they can't ignore the customers, and they need to be more demand status and consumer feedback to improve themselves.

\section{REFERENCES}

[1] Gan Lin. (2018). Strategic Management Research of $\mathrm{X}$ Company (Doctoral dissertation, China University of Science and Technology).

[2] Shan Wang. (2017). Research on strategic management of RX Company (Doctoral dissertation, University of International Business and Economics).

[3] Jian Han. (2019). Research on human resource management transformation of Shanghai E Company based on strategic management (Doctoral dissertation, Shanghai International Studies University).

[4] Dandan Song. (2016). Research on diversified transformation development of China's high-speed railway based on enterprise strategic management
Theory (Doctoral dissertation, China Academy of Railway Sciences).

[5] Jin Du. (2017). The application of design research method in enterprise strategic management (Doctoral dissertation, Southeast Univercity).

[6]Yunyu He. (2016). Research on strategic management of Sichuan H Construction Company (Doctoral dissertation, Southwest Jiaotong University).

[7] Xue Ju. (2017). Research on the diversification strategy optimization of PL Asset management Company (Doctoral dissertation, Zhejing Sic-Tech University).

[8] Min Li. (2019). Research on corporate diversification Strategy of SCE (Doctoral dissertation, Northwest University).

[9] Yuling Chen. (2017). Research on diversification Strategy of WHCHEM Group (Doctoral dissertation, Shandong University).

[10] Manxin Liu. (2015). Research on Marketing strategy of Thailand tourism Market based on 4P Theory: Taking Chinese tourists to Thailand as an example (Doctoral dissertation, Hunan Normal University).

[11] Jianwei Zhang. (2016). Research on integrated marketing communication of Tiny Times film series (Doctoral dissertation, Jiangxi University of Finance and Economics). 